\title{
Financial Distress and Firm Performance: Evidence from COVID-19
}

\author{
Caleb Cheng Ee Wan, Christine Teoh Kah Shu, Kong Jiunn Wenn, Marie Elizabeth Huong \\ Jia-Lin, Vivy Ling Su Chii \\ Faculty Economics and Business, Universiti Malaysia Sarawak
}

\begin{abstract}
This study is dedicated to discovering the impact of COVID-19 on Malaysia' plantation industry firms. This paper uses quarterly data from annual report of 39 listed firms from Malaysia from 2018 to 2020. The variables to measure financial distress are debt ratio and debt-to-equity ratio while the measurement for firm performance is return on assets. The findings show that there is a significant negative relationship between debt-to-equity ratio on firm performance. This indicates that the increase in debt-to-equity ratio results in a significant decrease in return on total assets. On the other hand, positive correlation exists between debt ratio and firm performance. This means that an increase in debt ratio results in an increase in the return value of total assets.
\end{abstract}

\section{INTRODUCTION}

Financial distress has brought attention from people from all walks of life. Undeniably, Asian Financial Crisis in 1997 has significantly affect the whole economic activity in Asian market as well as the depreciation in the currency. During the time of financial distress, the price of the goods and services has increased greatly, and cost of borrowing is higher. As such, it has result in the bad performance of stock market and firms face with difficulties in term of profit as they meet the shortage of cash flow in financing activities. A research by Pettinger (2020) pinpointed that Malaysia has experienced with a rapid devaluation in the period of financial distress. Countries face with high level of debt and there is more import than exports which will cause the deficits in current account of a country. When the country failed to generate more exports, it will result in the unbalanced of the economy growth. Firms will face with lower sales and profit and affect the performance. According to Hayes (2020), financial distress occurs when a business or company failed to produce adequate revenue or profit to fulfill and pay its financial obligations. There are some causes for this condition such as high operating expenses, high percentage of illiquid assets or income that is vulnerable to economic downturns. Some companies would face with financial distress during the global financial crisis and result in the high amount of debt or the expenses are high.

Next, De Fiore and Uhlig (2015) have concluded in their study that the financial crisis happened in 2008 has caused most of the firms to face with difficulties in operating and financing their economic activity. The cost of the loans increased significantly and result in the companies to experience with higher amount of debt. Companies are required to pay more when they start to apply for a loan, and they need more funds to cover the debts. When more funds are needed to fund and cover the debts, profit of the firms will get affected. Thus, the firms will fail to maintain their performance at a specific level. Amadeo (2020) studied that the 
global financial crisis in 2008 has become the worst economic disaster and many firms failed to generate more funds for their daily financing expenses. Banks were also experienced in high loss and they have decided to stop the transactions of lending funds. Thus, when the bank stops to provide and approve loan for firms, firms will meet the shortage of cash to solve their financial problem such as paying the interest to the investors in the firms. This research aims to investigate the firm performance and financial distress. The research conceptualization is frame under the Modigliani-Miller theorem and static trade-off theory. Using firms listed under plantation industry in Malaysia as the research context, this research tests the hypothesis by estimating a panel regression. The full detail of the research will be portrayed and discussed in five chapters. Within this chapter, the effects of access to finance by Small and Medium-sized Enterprises (SMEs) on organizational dynamics of the firms in countries around the world are introduced. Additionally, it consists of eight subchapters. To kick start this chapter, it includes the subchapter of the study background, problem statement, followed by research questions as the third subtopic and research objectives as the fourth. The next subchapter would be the contribution of this study with the scope of the study as the sixth. Then, subchapter seven would be the organization of the study and ending this chapter with a summary.

\section{LITERATURE REVIEW}

\section{Modigliani-Miller Theorem}

According to Breuer and Gurtler (2008), their studies mentioned that there are three essential version of M\&M theorem that can be drawn. First, value of firms is independent to capital structure of firms. Second, cost of equity is directly proportional to the debt-equity ratio and the next version is the dividend policy of firms is independent to its value. During a financial crisis, a company's debt or leverage can increase to a certain limit, affecting the firm's value. The first version of the Modigliani-Miller theorem stated that a company's value is independent of its capital structure and that a company's value can be measured using the present value of its potential earnings (Chen, 2020). Capital structure can be defined as the amount of liability and equity provided by a firm to fund its activities or operations, according to Tuovila (2020). As a result, M\&M concluded that the size of a company's debt has little bearing on its worth. According to Odgen, Jen, and O'Connor (2003), the first version of this theorem must take into account a few key assumptions about perfect efficiency markets. For example, free taxes, free transaction costs, and free bankruptcy costs are all conditions for a perfect market. As a result, in a perfect economy, a firm's valuation would be unaffected by its debt. Since there are no costs associated with purchasing and selling shares, investors are free to do so.

The second version of the M\&M theorem claimed that the cost of equity would rise in tandem with the debt-to-equity ratio in a company's capital structure (Ahmeti \& Prenaj 2015). In other words, increasing the debt-to-equity ratio would increase leverage and increase the risk of a company defaulting. When a business introduces itself to a higher default risk, the value of the company drops. As a result, investors and shareholders in companies prefer a higher return as a premium for the higher risk involved. It's difficult to always have a perfect efficiency market in the real world. As a result, the second version of the M\&M theorem is better suited to describe the actual state of the real economy, which includes transaction costs, taxation, and bankruptcy, among other things. Firms must consider both the risk of high debt and its effect on the firm's valuation. 


\section{Static Trade-off Theory}

Static trade-off theory is one of the few effective financial concepts for determining a firm's capital structure. When businesses mature, they consider a variety of financing options for their ventures and operating operations in order to gain a competitive edge. Firms may produce revenue in a variety of ways, including sales revenue, money from shareholders or investors, bond issuance, and so on. Firms use capital structure to fund their growth and determine what form of capital structure they want to achieve to get a higher valuation. Capital structure applies to the mix of debt and equity and is one of the forms firms use to finance their growth and identify what type of capital structure they want to achieve to get a higher value. The static trade-off theory, according to Chen (2004), indicates a positive relationship between benefit and firm leverage. This implies that increasing a firm's leverage would result in an increase in earnings. When a company's profit rises, it can draw more investors, which may help the company avoid financial difficulties and reduce the risk of bankruptcy. Furthermore, companies can do better and have a higher valuation.

The static trade-off theory is a theory of optimal capital structure that is linked to the valuation of a business. The capital structure of a company is important because it can affect the sum of weighted average cost of capital (WACC) and thus the firm's valuation. WACC will decrease as the capital structure improves, resulting in a higher firm value (Tarver, 2020). The payment of a firm's liabilities is tax-deductible under this theory, so the risk from using leverage over equity is reduced. Companies may find it simpler and less expensive to use debt financing rather than equity financing because debt financing does not require the business to pay any taxes. As a result, with high debt, this will increase the firm's valuation. This theory aims to strike a balance between the benefits of debt, such as the tax shield effect, and the costs of debt, such as the interest rate. If the cost of debt is not greater than the interest and tax benefits, a company's value will continue to rise. However, an excessive amount of debt could push the cost of a financial crisis for a company to its maximum level. When a company's financial burden is too great, it runs the risk of going bankrupt. This would have an impact on investors' decision to remain with the company because they will receive a lower dividend. According to Hayes (2020), the safest way to mix debt and equity is to use an efficient capital structure, which can help companies maximise their valuation.

\section{Hypothesis Development \\ Debt Ratio and Firms' Value}

In brief, the amount of debt of firms plays an important role in determining the value of firms be it in an increase or decrease manner. Based on a study conducted by Chen and Chen (2011), it was mentioned that the debt and value of firms do not share a positive relationship. The research was conducted by analysing 647 listed firms based in Taiwan and was concluded that firms that experience a high level of leverage could in turn decrease its value. They then stated that in the events that the interest of tax shield exceeds the cost of debt, firms should maintain a lower leverage. However, a significant increment in debt could lead to a higher cost of debt which in the end decreases the ROA of firms. Furthermore, a research by Hull (2004) stated that when the debt of firms has increased to its peak, firms will begin to experience a drop in value which also increases their risk of going bankrupt. When firms are exposed to high risk of bankruptcy, it causes them to decrease in profit which in turn results in a lower ROA. Moreover, the author also mentioned that when firms are searching for additional sources of finance for its daily operations, firms ought to have the ability to keep the amount of debt under control. 
However, there are also other studies which reported findings which contradicts with the papers aforementioned. Based on a research conducted by Karaca (2012) through the observation of financial ratio of Turkish firms along with its effects to firm value for a period of 8 years. His study reached the conclusion that debt ratio and firms' valuation do not share an essential connection. This implies that the increment in the debt of firms does not necessarily affect the ROA, which is consistent with the concept of M\&M theorem. On the other hand, a research by Hol and Wijst (2008) introduced the factor of size into their studies whereby they discovered that firm size may affect its value depending on the amount of leverage. They mentioned that firm size affects the leverage of firms and stated that larger firms generally have lower leverage and lower risk as compared to smaller firms. With lower leverage and lower risk, larger firms experience low risk of bankruptcy which provides them with the edge in the stock market. Besides, the process of obtaining additional funds for the purpose of financing operational activities would be fairly easy. Therefore, firms with low leverage will have a better performance exhibited through higher profit and a stronger ROA.

Based on a research conducted by Lin and Chang (2011), their study concluded that firms' value can be enhanced by implementing the optimal debt ratio. The study was conducted with a sample of 196 Taiwanese firms, and they observed that the value of firms will increase in tandem with its debt ratio until it reaches a maximum level of debt, which is consistent to the concept of the static trade-off theory. In clearer terms, they stated that when the amount of debt ratio exceeds $33 \%$, the value of the firm would cease to increase. This implies that there is no positive correlation between debt ratio and firm value when the debt ratio of the firm exceeds the amount that offsets the benefits from tax shield or is too high. Based on the findings from previous literatures, we develop the first hypothesis for this study to test the relationship between debt ratio and firms' value. The hypothesis developed is as exhibited below:

$\mathrm{H}_{1}$ : There is a significant relationship between debt ratio and ROA.

\section{Debt-to-Equity Ratio and Firms' Value}

A research by Notta and Vlavchvei (2014) which observes 126 large Greek food manufacturing firms has observed that the effects of a global financial crisis in year 2007 has caused impact to the value of the firms in their study. By observing and comparing the performance of the firms from two different periods namely pre-crisis and during crisis, they proposed a new model that compares the profit of firms with the addition of equity, market share, leverage and liquidity. The findings of the paper showed that in times of financial crisis, leverage and equity of firms share a negative relationship with the profitability of firms. This implies that the firms' profit will be diminished and results in a lower ROA during financial crisis, which is consistent with the Pecking Order Theory that there is a negative correlation between debt and firms' profit. Based on the research by Khadafi, Heikal and Ummah (2014), their study stated that the debt-to-equity ratio and firm value share a significant and negative relationship. They conducted their research on a sample that comprises of automotive firms listed in the Indonesia Stock Exchange. The findings of the study concluded that the increment in debt-to-equity ratio leads to the decrease in firms' value. However, a research by Chowdhury and Chowdhury (2010) provided contradicting results. By observing the debt-to-equity ratio and firms' value, they concluded that there is a significant and positive relationship which goes against the concept stated in M\&M. 
Moreover, according to Ravid and Sekerci (2020), they mentioned that the increase in shareholders equity through large block-holders of the firms could increase firms' value provided that the portfolios held under block-holders are heavily weighted in company's stock. Furthermore, the study also claimed that the amount of shareholder equity through investment is crucial in maintaining the valuation of firms because it avoids the negative effect of dual-class structure in firms. When firms have sufficient capital for funding, they do no need to apply banks loans which could bring them a higher profit which in turn increases firms' value. Furthermore, a research by Adenugba and Kesinro (2016) discovered that the increment in firms' equity impacts the firms' value to increase as well. They stated that equity can act as an additional resource which provides extra funds to the firm in times of need. However, their findings differ from other literatures whereby it was stated that there is no significant relationship between shareholder equity and firms' value. On the other side of the coin, in the events when firms fail to generate sufficient capital from its shareholders, firms would seek for other alternatives to borrow the funds needed which results in a higher financial leverage. Ergo, this indicates that firms' value is significantly affected by the amount of debt.

Del Brio, De Miguel and Pindado (2003) conducted a research using Spanish firms with the purpose to identify the relationship shared between amount of investment and firms' value. They mentioned that the increase in the amount of investment increases the total shareholder equity which then provides a lower debtto-equity ratio. However, they claimed that there is an existence of an inverse relationship between the amount of investment and firms' value whereby the increase in the amount of in a very large quantity could results in the decrease in firms' value. By observing the findings of previous studies, the second hypothesis is developed for this study to test the relationship between debt-to-equity ratio and firms' value. The hypothesis developed is as shown below:

$\mathrm{H}_{2}$ : There is significant relationship between debt-to-equity ratio and ROA.

\section{METHODOLOGY}

\section{Research Design}

This study utilizes descriptive research to identify the association between the independent variables which are debt ratio and debt-to-equity ratio, and the dependent variable which is firm's performance is determined by the return on asset ratio (ROA). Three control variables are also included to isolate their effects on firm performances. The control variables are firm size and market-to-book. This study also utilizes secondary data which provides numerous advantages as compared to primary data. Then, panel research is conducted to analyze the effect of the independent variables on the dependent variable.

\section{Estimation Model}

The model used in this research for the purpose of identifying the effects of financial crisis on the performance of Malaysia firms from year 2007-2011 is shown below:

$$
R O A=\beta_{0}+\beta_{1} D R+\beta_{2} D E+\beta_{3} F S+\beta_{4} M B+\varepsilon
$$


Where:

ROA $=$ Firm's performance (Return on Total Asset)

$D R=$ Debt ratio

$D E=$ Debt-to-equity ratio

$F S=$ Firm size

$M B=$ Market-to-book ratio

$\beta_{0} \beta_{1} \beta_{2} \beta_{3} \beta_{4}=$ Coefficients

$\mathcal{E}=$ Error Term

\section{Measurement of Variables \\ Dependent Variable}

Firms' value act as the dependent variable in this study and is measured by calculating the return on total asset ratio. ROA is used as one of the measurements to measure how well the firms can make profit through the total assets. Besides, ROA is chosen as its calculation involve the debt of firms. ROA can be generated by dividing the net income of the firm by its total assets. Higher amount of debt will result in a larger amount of total asset of firms and hence affect ROA to be smaller. Greater value of ROA indicates that firms manage their assets more efficiently to generate more profit and it is good for a firm.

$$
\text { Return on Assets }=\frac{\text { Net Income }}{\text { Total Assets }}
$$

\section{Independent Variables}

There are two independent variables used in this study which are debt ratio and debt-to-equity ratio. Debt ratio is calculated by dividing the total debt by total assets of the firm. When the debt of the company is higher and result in a debt ratio with more than 1, this indicates that the firm has more amount of debt than assets. Meanwhile, when the debt ratio is less than 1 , it indicates that amount of assets is higher than debt.

$$
\text { Debt Ratio }=\frac{\text { Total Debt }}{\text { Total Assets }}
$$

The next independent variable is debt-to-equity ratio. It can be attained by dividing total liabilities over total shareholders' equity of the firm. When the value of debt is high, it will lead the shareholders of the firm to face a high risk in investing. A company with a debt-to-equity ratio of 2 implies that it has RM2 of debt for every RM1 of equity. On the other hand, negative ratio shows that firms have higher debt than assets and a negative shareholder equity.

$$
\text { Debt-To-Equity Ratio }=\frac{\text { Total Liabilities }}{\text { Total Shareholders'Equity }}
$$

\section{Control Variables}

The control variables used for this research are firm size and market-to-book for the purpose of eliminating all size related affections. 


\section{Firm Size}

Next, firm size is important for this research as this control variable estimates the financial characters of a firm, which aids in understanding the firm performance in the crisis period. Firm size is an imperative measure as it significantly affects profitability and efficiency of a firm. It can be obtained from total assets, total sales or market value of equity. Firm size will be determined through the total assets of firms for this study.

$$
\text { Firm Size }=\log (\text { Total Assets })
$$

\section{Market-to-book}

As for market-to-book, it is obtained by dividing the firm's market capitalization by book value or total assets minus total liabilities. The market-to-book ratio is included for comparing the market value of a firm with its book value. A market-to-book ratio that is more than 1 indicates that the firm's stock is overvalued meanwhile, a ratio less than 1 implies the stock is undervalued or a good market-to-book ratio for investment.

$$
\text { Market-to-Book Ratio }=\frac{\text { Market Capitalization }}{\text { Book Value }}
$$

\section{Data and Sample}

The firms that have been chosen in this study are 39 listed plantation firms in Bursa Malaysia. The data required is sourced from quarterly reports of each firm in the pre-crisis year of 2018 and 2019 with a total observation of 312 and during the crisis year of 2020 with a total observation of 156 . In addition to that, Stata is also utilized in this study to analyze time series, cross-sectional data and panel data.

\section{Data Analysis}

Descriptive analysis is used to define the relationship of dependent variable and independent variables. Basically, descriptive analysis is conducted to summarize the data of ROA of the firms. Descriptive analysis consists of measurement of central tendency (calculation of mean, median and mode of the data) and measurement of variability which aims to identify the maximum and minimum value of the data as well as the standard deviation and variance. In short, it can be defined as the dispersion's value of a dataset. Apart from that, Pearson's correlation focuses on finding out the correlation of dependent variable and independent variables in this study. The findings of Gujarati and Peter (2009) stated that the value that lies in the range of -1 and +1 are considered as correlation coefficient, $r$. Value with +1 indicate the association of the 2 variables is strong. However, value with -1 shows the two variables are strongly negative correlated with each other. Two variables that do not affect each other is when the value of $r$ is zero. Furthermore, panel data analysis will also be used. Panel data refers to the use of both time series data and cross-sectional data. They are used to identify the correlation between dependent variable and independent variables. Time series data involves the date of one company but several years while cross-sectional data consists of one year but many companies. Hence, combination of these two are important to use whereby the data are taken from 39 plantation firms with a time period of five years. 
Lastly, Ordinary Least Square (OLS) is used to identify the regression line of the correlation between independent variables and dependent variable. In order to achieve an unbiased and constant OLS, the coefficients and the intercept have to be homogeneous where zero mean of error term and there is zero association between independent variables and error term. OLS can be tested by T-test and F-test. When the computed p-value in OLS estimator is smaller than alpha equal to 0.05 , null hypothesis will be rejected, and it will be concluded that the model is significant.

\section{Diagnostic Test \\ Multicollinearity}

Multicollinearity is important to conclude whether the data recorded is acceptable or not. In other words, it aims to investigate the exact or inexact linear correlation between the independent variables in this study. One of the ways to conduct this test is through Variance Inflation Factor (VIF) test. When the value of VIF is high, it implies that there is high multicollinearity and independent variables are highly correlated with each other. If the computed VIF exceeds $5, \mathrm{H}_{0}$ will be rejected which implies the existence of strong correlation between the independent variables. On the contrary, when the computed VIF is equivalent to 1, the null hypothesis is to be rejected. The hypothesis for this test is as depicted below:

$H_{0}$ : Multicollinearity does not exist.

$H_{1}$ : Multicollinearity exist.

Calculation of VIF is shown as below:

$$
\mathrm{VIF}=\frac{1}{1-R^{2}}
$$

\section{Heteroscedasticity Test (White)}

When the errors in statistic do not have constant variance, it can be said that the problem of heteroscedasticity exists. When heteroscedasticity exists, the Ordinary Least Square (OLS) estimators remains unbiased. Besides that, the OLS estimators are inefficient whereby it no longer has the minimum variance. At $5 \%$ significance level, the null hypothesis will be rejected if the p-value $\leq 0.05$, which implies that heteroscedasticity exists. As expressed below is the hypothesis for the test:

$H_{0}$ : Heteroscedasticity does not exist.

$H_{1}$ : Heteroscedasticity exist.

\section{Shapiro-Wilk Test (Normality)}

The Shapiro-Wilk test targets to analyze whether the data of the variables attained in the model is distributed normally or otherwise. The premise of the Shapiro-Wilk test is that data taken from a population are usually distributed normally. When the p-value for a variable is smaller than the value of 5\% significance level, null hypothesis will not be accepted and it illustrates that the variable is not distributed normally. Thus, the hypothesis developed is as shown below:

$H_{0}$ : A variable is normally distributed in some population.

$H_{1}$ : A variable is not normally distributed in some population. 


\section{Wooldridge Serial Correlation Test}

Wooldridge Serial Correlation Test otherwise known as autocorrelation test, is a test utilized to detect the existence of autocorrelation issues. In brief, autocorrelation can be categorized as two types namely first order serial correlation and second order serial correlation. When the p-value is smaller than the value of 5\% significance level, the null hypothesis is to be rejected and it illustrates that autocorrelation exists. As exhibited below is the hypothesis:

$H_{0}$ : Autocorrelation does not exist.

$H_{1}$ : Autocorrelation exist.

\section{Breusch and Pagan Lagrangian Multiplier Test}

To determine whether to apply Pooled OLS or panel regression model, the BP test was adopted. The null hypothesis in a BP test is that the variance of the random effects is equal to zero while the alternative hypothesis is that the variance of panel regression is not equal to zero. If the p-value is less than 5\% significance level, the null hypothesis is rejected and therefore, the panel regression model is the most appropriate model to use in the study. However, if the p-value is greater than $5 \%$ significance level, we do not reject the null hypothesis. Therefore, the null and alternative hypotheses can be stated as follows:

$H_{0}$ : Pooled Ordinary Least Square Model.

$H_{1}$ : Panel Regression Model.

\section{Hausman Test}

To select which model between fixed effects (FEM) and random effects (REM) is more suitable to adopt in this study, the Hausman test was conducted. The FEM assumes that the slope coefficients of the independent variables do not differ between individuals or over time. The interception in the regression model may differ because each individual or cross-sectional unit has its own particular characteristics. If the individual-specific intercept is correlated with independent variable, then FEM is appropriate. Nevertheless, REM assumes that the interception of individual units from a much larger population is a random drawing with a constant mean value (Gujarati and Porter, 2009). If the intercept is uncorrelated with independent variables, then REM is appropriate. If the p-value is less than 5\% significance level, the null hypothesis is rejected and therefore, the fixed effect model is the most appropriate model to use in the study. However, if the p-value is greater than 5\% significance level, we do not reject the null hypothesis. Thus, the hypotheses underlying the Hausman test are stated as below:

$H_{0}$ : Random Effects Model.

$H_{1}$ : Fixed Effects Mode 


\section{RESULTS}

\subsection{Description of the Empirical Models}

Table 1: Descriptive Statistic for the Dependent, Independent and Control Variables for Pre-Crisis and Crisis.

\begin{tabular}{|c|c|c|c|c|c|c|c|}
\hline \multicolumn{8}{|c|}{ Pre-crisis } \\
\hline Variable & Min & Q1 & Median & Mean & Q3 & Max & Std. Dev. \\
\hline ROA & -20.720 & -1.980 & 0.225 & 0.436 & 2.070 & 75.730 & 6.018 \\
\hline DR & 0.000 & 0.190 & 0.365 & 0.365 & 0.480 & 1.220 & 0.207 \\
\hline DE & 0.000 & 0.230 & 0.580 & 0.713 & 0.930 & 5.470 & 0.739 \\
\hline LEV & 0.000 & 0.000 & 0.200 & 0.210 & 0.360 & 1.770 & 0.207 \\
\hline FS & 0.000 & 8.710 & 9.020 & 8.966 & 9.420 & 10.460 & 1.282 \\
\hline MB & 0.000 & 0.740 & 1.075 & 1.211 & 1.605 & 3.450 & 0.732 \\
\hline \multicolumn{7}{|c|}{} & \multicolumn{7}{|c|}{ Crisis } & & & \\
\hline Variable & Min & Q1 & Median & Mean & Q3 & Max & Std. Dev. \\
\hline ROA & -8.930 & -1.040 & 1.755 & 2.871 & 5.105 & 60.150 & 7.381 \\
\hline DR & 0.000 & 0.170 & 0.355 & 0.335 & 0.460 & 0.700 & 0.190 \\
\hline DE & 0.000 & 0.210 & 0.540 & 0.646 & 0.850 & 2.330 & 0.548 \\
\hline LEV & 0.000 & 0.020 & 0.190 & 0.198 & 0.345 & 0.950 & 0.183 \\
\hline FS & 0.000 & 8.710 & 9.050 & 9.074 & 9.415 & 10.460 & 0.922 \\
\hline MB & 0.000 & 0.410 & 0.940 & 1.067 & 1.495 & 3.210 & 0.711 \\
\hline
\end{tabular}

The firm performance of plantation industry firms is measured with their return on assets. The quarterly mean return on assets for pre-crisis period is 0.436 and 2.871 during crisis. The standard deviation for pre-crisis and crisis is 6.018 and 7.381, respectively. The median of return on assets is 0.225 for pre-crisis and 1.755 for crisis. The minimum of return on performance is -20.720 in pre-crisis while -8.930 for crisis. The maximum for pre-crisis is 75.730 and 60.150 for crisis. For the $25^{\text {th }}$ percentile in pre-crisis period is 1.980 and it is -1.04 during crisis whereas $75^{\text {th }}$ percentile, pre-crisis period has 2.070 and 5.105 in crisis. There are two independent variables in this model to determine the financial distress of firms. One of the independent variables for this regression is debt ratio. The mean depicts per-crisis period has a higher value with 0.365 while crisis period has a mean ratio of 0.335 . The standard deviation of pre-crisis is 0.207 and 0.190 for crisis period. It has a median of 0.365 in pre-crisis period while a lower value of 0.355 in year of crisis with a $25^{\text {th }}$ percentile of 0.190 (pre-crisis) and 0.170 (crisis). The $75^{\text {th }}$ percentile for pre-crisis is at 0.480 , which is higher than crisis year which is 0.460 . The minimum of debt ratio for pre-crisis and crisis years is 0.000 while the maximum for pre-crisis year is 1.220 and 0.700 for crisis.

Then, the debt-to-equity ratio, as the other independent variable has a higher mean at pre-crisis year with 0.713 and crisis period has 0.646 . The standard deviation of pre-crisis is 0.739 , and 0.548 at crisis period. Debt-to-equity ratio has its minimum at 0.000 for both periods and a maximum of 5.470 (pre-crisis) and 2.330 (crisis). The median falls on 0.580 for pre-crisis and 0.540 in crisis period. The $25^{\text {th }}$ percentile of debt-to- 
equity ratio is 0.230 in pre-crisis period which is higher than crisis period at 0.210 while the $75^{\text {th }}$ percentile is 0.930 (pre-crisis) and 0.850 (crisis).

\section{Pearson Correlation}

Table 2: Pearson Correlation

\begin{tabular}{|c|c|c|c|c|c|}
\hline \multicolumn{6}{|c|}{ Pre-Crisis } \\
\hline & ROA & DR & DE & FS & MB \\
\hline ROA & 1.0000 & & & & \\
\hline DR & $-0.3387 *$ & 1.0000 & & & \\
\hline DE & $-0.3365^{*}$ & $0.8192 *$ & 1.0000 & & \\
\hline FS & 0.0761 & $0.2788^{*}$ & $0.1245^{*}$ & 1.0000 & \\
\hline MB & -0.0180 & $0.5745^{*}$ & $0.5266^{*}$ & $0.3504 *$ & 1.0000 \\
\hline \multicolumn{6}{|c|}{ Crisis } \\
\hline & ROA & DR & DE & FS & MB \\
\hline ROA & 1.0000 & & & & \\
\hline DR & $-0.2126^{*}$ & 1.0000 & & & \\
\hline DE & $-0.2282 *$ & $0.9330 *$ & 1.0000 & & \\
\hline FS & 0.0165 & $0.3778 *$ & $0.2959 *$ & 1.0000 & \\
\hline MB & 0.0690 & $0.5449 *$ & $0.4820^{*}$ & $0.4236^{*}$ & 1.0000 \\
\hline \multicolumn{6}{|c|}{$\mathbf{P}<0.05=*$} \\
\hline
\end{tabular}

The result states that the return on asset is significantly related with debt ratio and debt-to-equity ratio for all periods at $5 \%$ significance level. This means that when a company increase the use of debt, the firm performance of the respective firm decreases in year 2018 to 2020 in Malaysia. On the other hand, in year 2018 to 2020, the return on asset is negatively related to debt ratio and debt-to-equity. Hence, it supports the Modigliani-Miller Theorem whereby when the debt level of a firm increases, the firm has a higher risk of countering financial distress. The phenomenon supports hypothesis 1 and hypothesis 2 . As for the control variables, firm size and market-to-book ratio is positively related with return on assets and are insignificant for both periods.

\section{Diagnostic Test Result Multicollinearity Test}

The first diagnostic test introduced to the regression is the Multicollinearity Test which is used to identify the issue of multicollinearity among the independent variable. After conducting the test on the precrisis and crisis period, the mean VIF generated are 2.41 and 4.93, respectively. By observing the mean VIF generated, both models of pre-crisis and crisis period do not exceed the value of 5. Therefore, we do not reject the null hypothesis for the Multicollinearity Test for both models. Thus, there is sufficient statistical evidence to conclude that the issue of multicollinearity is absent from the models. 


\section{Heteroscedasticity Test}

The Heteroscedasticity Test otherwise known as the White Test, is utilized to identify the existence of heteroscedasticity of the error term in a regression. After performing the Heteroscedasticity Test on the models of pre-crisis and crisis period, the p-value obtained for both models are 0.0000 . With a p-value lower than 0.05 , the null hypothesis is rejected for the models of pre-crisis and crisis period. Hence, the conclusion drawn here is that the issue of heteroscedasticity exists in both models at the $5 \%$ level of significance.

\section{Shapiro-Wilk Test}

The Shapiro-Wilk Test is also conducted on the regression to examine the normality of data for each variable in the model. After conducting the Shapiro-Wilk Test on the models of pre-crisis and crisis period, the $\mathrm{p}$-values for each variable are obtained for interpretation. To begin with, the test on the pre-crisis model exhibits the variables with their respective p-values are ROA (0), DR (0), DTER (0) FS (0) and MB (0). As for the crisis model, the variables and their respective p-values are ROA (0), DR (0.00077), DTER (0) FS (0) and MB (0.00001). By observing the p-values for each variable from both models, it is obvious that none of the p-values exceed the 0.05 threshold. Thus, the null hypothesis is rejected for all six variables from both models, which thereby concludes that the data for each variable are not normally distributed for the pre-crisis and crisis model.

\section{Wooldridge Serial Correlation Test}

Moreover, the Wooldridge Serial Correlation Test is conducted on the regression to identify the existence of autocorrelation issue in the model. After the test is conducted for both the models from the precrisis and crisis period, the p-value is then utilized for purpose of interpretation. The p-value of the pre-crisis model indicates the value of 0.0528 which has exceeded the 0.05 significance level. Therefore, the null hypothesis is not rejected, thereby concluding that the issue of autocorrelation does not exist in the pre-crisis model. Then, the p-value of the crisis model exhibits the value of 0.0000 which is lower that the 0.05 significance level. Therefore, the null hypothesis is not rejected and there is sufficient statistical evidence to conclude that the issue of autocorrelation exists in the crisis period model.

\section{Breusch and Pagan Lagrangian Multiplier Test}

The result obtained from this diagnostic test proved that the regression for both pre-crisis and crisis periods are applying panel regression. The p-value from the result is 0.000 and 0.0018 for pre-crisis and crisis, respectively. With significant level at $5 \%$, the conducted p-value is lower than 0.05 . Hence, it suggests that the model for both periods is panel regression.

\section{Hausman Test}

The p-value obtained is 0.000 and 0.1291 for pre-crisis and crisis, respectively. With the level of significance at $5 \%(\alpha=0.05)$, the $p$-value for pre-crisis years is lower than the level of significance. This means that the model for pre-crisis portray a fixed effect model. On the other hand, crisis year has a p-value higher than 0.05 . This depicts that the model for crisis year is a random effect mode 


\section{Panel Regression Result}

Table 3: Panel Regression Result

\begin{tabular}{|c|c|c|}
\hline & 2018 & 2020 \\
\hline & ROA & ROA \\
\hline \multirow[t]{2}{*}{$\overline{D R}$} & $-21.1244 *$ & -6.9590 \\
\hline & $(10.5517)$ & $(11.9647)$ \\
\hline \multirow[t]{2}{*}{$\mathbf{D E}$} & $-4.9237^{*}$ & -3.1417 \\
\hline & $(2.4101)$ & $(3.1803)$ \\
\hline \multirow[t]{2}{*}{ FS } & $0.9619 * *$ & $0.6086^{*}$ \\
\hline & $(0.2836)$ & $(0.2888)$ \\
\hline \multirow[t]{2}{*}{ MB } & 0.1526 & $2.6239 * *$ \\
\hline & $(0.8650)$ & $(0.9909)$ \\
\hline \multirow[t]{2}{*}{ Constant } & 2.3952 & -1.0882 \\
\hline & $(3.4134)$ & $(3.3099)$ \\
\hline \multicolumn{3}{|c|}{$\mathbf{P}<0.05=*, \mathbf{P}<0.01=* *$} \\
\hline$N$ & 312 & 156 \\
\hline $\mathbf{r}^{2}$ & 0.3343 & 0.0980 \\
\hline${\text { Adjusted } \mathbf{r}^{2}}^{2}$ & 0.3256 & 0.0741 \\
\hline
\end{tabular}

The relation between return on assets and debt ratio is -21.1244 with significant level at 5\% for precrisis with -6.9590 in crisis period. While pre-crisis period shows that debt ratio is significant, crisis period shows otherwise. In other words, during pre-crisis period, when the debt ratio increases by RM1, return on assets decrease by RM 21.12. During crisis year, when the debt ratio increases by RM1, the plantation industry has a decrease in return on assets of RM 6.96. This shows that crisis period has a lower decrease while precrisis has a higher decrease. This situation is depicting that return-on-asset decrease less in crisis period as compared to pre-crisis. Similarly, the relationship between return on asset and debt-to-equity ratio, all periods portray a negatively related relationship with -4.9237 (pre-crisis) and -3.1417 (crisis). Pre-crisis period reflects that it is significant at 5\% significance level while crisis is significant. To further explain, when debtto-equity ratio increases by RM 1, return on assets decreases by RM4.92 in pre-crisis period. On the other hand, when there is a RM 1 increase in debt-to-equity ratio, return on assets decreases by RM3.14 in crisis period. This depicts that in pre-crisis period, debt-to-equity ratio decrease return-on-assets more than crisis period. Nevertheless, this well explained by Modigliani-Miller Theorem that debt ratio and debt-to-equity ratio are negatively related with return on assets.

As for the other variables, firm size has 0.9619 (pre-crisis) and 0.6086 (crisis). This means that when firm size increase by RM 1, return on assets increases by RM 0.96 in pre-crisis period while in crisis period, when the firm size increases by RM 1, return on assets increases by RM 0.61. In pre-crisis period, it is significant at $1 \%$ while crisis period is $5 \%$. However, firm size has a lesser effect on return on assets in crisis period as compared by pre-crisis period. On the other hand, market-to-book ratio has 0.1526 in pre-crisis period while 2.6239 in crisis period. Hence, when market-to-book ratio increase by RM 1, return on assets increases by RM 0.15 in pre-crisis period while RM 2.62 in crisis period and is significant at $1 \%$ significance level. It has a lesser effect in pre-crisis period as compared with crisis period. The model for pre-crisis period has an adjusted r-square of 0.3256 . Hence, the independent variable of this model, debt ratio, debt-to-equity 
ratio, firm size and market-to-book ratio are able to explain the return-on-assets for $32.56 \%$. As for the crisis period, it has an adjusted ratio of 0.0741 , which equals to $7.41 \%$. This shows that debt ratio, debt-to-equity ratio, firm size and market-to-book ratio is able to explain $7.41 \%$ of the return on assets in crisis period. In other words, there are more variables for the explanation on changes of return on assets in crisis period.

\section{CONCLUSION}

This study was carried out with the aim of determining the correlation between financial distress and firm performance of a sample of 39 listed plantation firms in Malaysia using the data from the pre-crisis year (2018-2019) to the crisis year (2020). Firm performance was measured using return on asset ratio and capital structure of debt ratio and debt-to-equity ratio with firm size and market-to-book ratio as the controlled variables. This study used descriptive analysis, correlation analysis and diagnostic tests such as multicollinearity, autocorrelation and normality test to examine the relationship between dependent and explanatory variables to achieve this research's objectives. Throughout the analysis of data, it is found that there is a significant negative relationship between debt-to-equity ratio on firm performance. This indicates that the increase in debt-to-equity ratio results in a significant decrease in return on total assets. On the other hand, positive correlation exists between debt ratio and firm performance. This aligns with Modigliani-Miller Theorem as when there is an increase in debt ratio results in an increase in the return value of total assets. These results were consistent and supported by previous researchers who conducted their research on similar subjects. Therefore, this study implies the conclusion that capital structure plays an imperative role in determining firm performance of Malaysia's plantation industries. This research is useful for shareholders to understand the relationship between financial distress and firm performance. This is because financial distress may be a key factor to better understand the changes in firm performance. This allows them to better understand the market they are engaged in. Better firm performance aids the investors to have a clearer view of the selected firms so that they make wiser decisions by avoiding those that are not in favour of their investment. As for the industry, this study is useful for understanding the early warnings of company defaulting. These early warnings may show in the changes in debt value, specifically when the firm is facing financial distress moments. As such, related parties should take note when firms exhibit low firm value.

\section{REFERENCES}

Adenugba, A. A., Ige, A. A., \& Kesinro, O. R. (2016). Financial leverage and firms' value: A study of selected firms in Nigeria. European Journal of Research and Reflection in Management Sciences, 4(1).

Ahmeti, F., \& Prenaj, B. (2015). A critical review of Modigliani and Miller's theorem of capital structure. International Journal of Economics, Commerce, and Management (IJECM), 3(6).

Amadeo, K. (2020). 2008 Financial crisis. The balance. Retrieved from https://www.thebalance.com/2008financial-crisis-3305679

Andrade, G., \& Kaplan, S. N. (1998). How costly is financial (not economic) distress? Evidence from highly leveraged transactions that became distressed. The journal of finance, 53(5), 1443-1493.

Breuer, W., \& Gurtler, M. (2008). 50 years after MM: recent developments in corporate finance. Journal of Business Economics 6.

Chen, J. (2020). Modigliani-Miller Theorem. Investopedia. Retrieved from https://www.investopedia.com/terms/m/modigliani-millertheorem.asp 
Chen, J. J. (2004). Determinants of capital structure of Chinese listed companies. Journal of Business Research, 57(12), 1341-1351.

Chen, L. J., \& Chen, S. Y. (2011). The influence of profitability on firm value with capital structure as the mediator and firm size and industry as moderators. Investment Management and Financial Innovations, 8(3), 121-129.

Cheng, M. C., \& Tzeng, Z. C. (2011). The effect of leverage on firm value and how the firm financial quality influence on this effect. World Journal of Management, 3(2), 30-53.

Chowdhury, A., \& Chowdhury, S. P. (2010). Impact of capital structure on firm's value: Evidence from Bangladesh. Business and Economic Horizons (BEH), 3(1232 -2016-101116), 111-122.

De Fiore, F., \& Uhlig, H. (2015). Corporate debt structure and the financial crisis. Journal of Money, credit and Banking, 47(8), 1571-1598.

Del Brio, E., De Miguel, A., \& Pindado, J. (2003). Investment and firm value: an analysis using panel data. Applied Financial Economics, 13(12), 913-923.

Gujarati, D. N., \& Porter, D. C. (2009). Basic Econometrics (5th ed.). Boston: 77 McGraw-Hill Irwin.

Gujarati, D. N., \& Porter, D. C. (2009). Basic Econometrics (5th ed.). Boston: 77 McGraw-Hill Irwin.

Hayes, A. (2020). Debt ratio definition. Investopedia. Retrieved from https://www.investopedia.com/terms/d/debtratio.asp

Hayes, A. (2020). Optimal capital structure. Investopedia. Retrieved from https://www.investopedia.com/terms/o/optimal-capital-structure.asp

Hol, S., \& Wijst, N. V. D. (2008). The financial structure of non listed firms. Applied Financial Economics, 18(7), 559-568.

Hull, R. M. (2004). Firm value and the debt-equity choice. Washburn University School of Business.

Karaca, S. S., \& Savsar, A. (2012). The effect of financial ratios on the firm value: Evidence from Turkey. Journal of Applied Economic Sciences, 7(1), 56-63.

Khadafi, M., Heikal, M., \& Ummah, A. (2014). Influence analysis of return on assets (ROA), return on equity (ROE), net profit margin (NPM), debt to equity ratio (DER), and current ratio (CR), against corporate profit growth in automotive in Indonesia Stock Exchange. International Journal of Academic Research in Business and Social Sciences, 4(12).

Lin, F. L., \& Chang, T. (2011). Does debt affect firm value in Taiwan? A panel threshold regression analysis. Applied Economics, 43(1), 117-128.

Notta, O., \& Vlachvei, A. (2014). The impact of Financial Crisis on firm performance in case of Greek food manufacturing firms. Procedia Economics and Finance, 14, 454-460.

Ogden, J. P., Jen, F. C., \& O'Connor, P. F. (2003). Advanced corporate finance: Policies and strategies. Upper Saddle River, N.J: Prentice Hall.

Pettinger, T. (2020). Asian Financial Crisis 1997. Economicshelp Retrieved from https://www.economicshelp.org/blog/glossary/financial-crisis-asia-1997/

Ravid, S. A., \& Sekerci, N. (2020). Large investors' portfolio composition and firms' value. Journal of Corporate Finance, 61, 101404.

Tarver, E. (2020). Which financial principles help companies choose capital structure. Investopedia. Retrieved from https://www.investopedia.com/ask/answers/052215/does-tradeoff-model-orpeckingorder-play-greater-role-capital-budgeting.asp

Tuovila, A.. (2020). Capital structure. Investopedia. Retrieved from https://www.investopedia.com/terms/c/capitalstructure.asp 